\title{
ETHIOPIA
}

\section{Cows, missing milk markets and nutri- tion in rural Ethiopia}

John Hoddinott*, Derek Headey, ${ }^{* *}$, and Mekdim Dereje (*** $^{* *}$

* Senior Research Fellow and Deputy Director, Poverty, Health and Nutrition Division, International Food Policy Research Institute

** Research Fellow, Poverty, Health and Nutrition Division, International Food Policy Research Institute

*** Research Officer, International Food Policy Research Institute - Ethiopia Strategy Support Program, and Ethiopian Development Research Institute 


\section{Table of Contents}

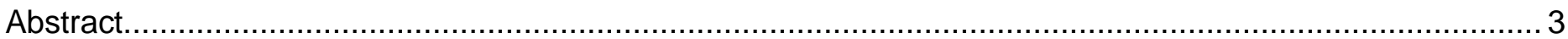

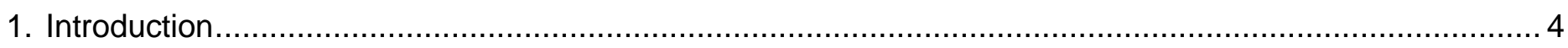

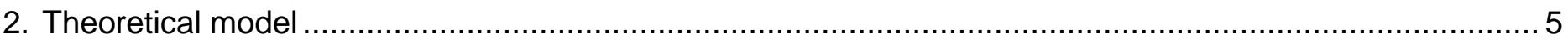

3. Data

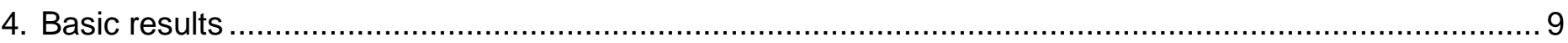

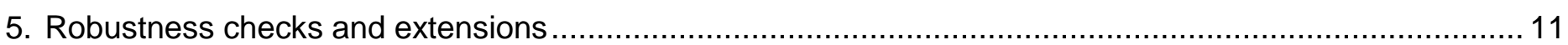

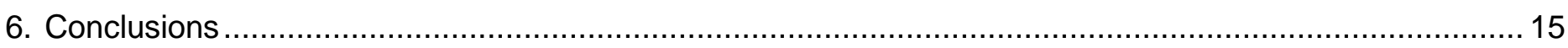

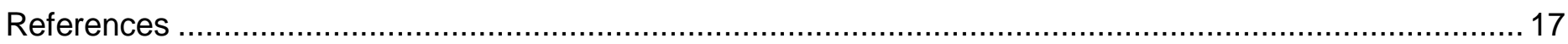

\section{List of Tables}

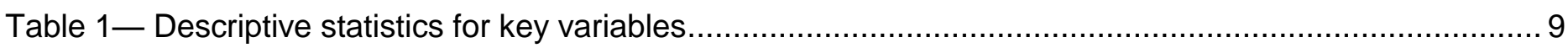

Table 2- Milk consumption by children aged 6 to 24 months................................................................. 10

Table 3- Association between child height and ownership of cows by child age groups............................ 10

Table 4- Association between child weight and ownership of cows by child age groups .......................... 10

Table 5- Milk consumption, child height and cow ownership by access to food markets ............................ 11

Table 6- Milk consumption, child height, and cow ownership, with controls for locality-level cow ownership

Table 7- Does cow ownership increase the likelihood of consuming other high value foods? A placebo

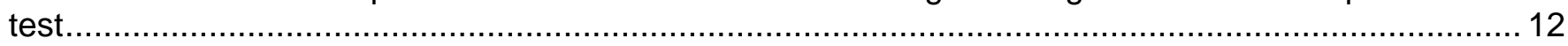

Table 8- Milk consumption, child height, and cow ownership, with controls for crop and livestock

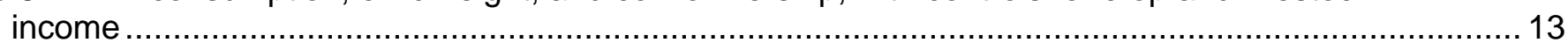

Table 9- Milk consumption, child height, and cow ownership, with additional controls for locality characteristics

Table 10- Extension of tests to the 2000 Ethiopian Demographic Health Survey (EDHS)

\section{List of Figures}

Figure 1-AGP enumeration areas (dark circles), major markets (light circles), and woreda level population density 


\begin{abstract}
In rural economies encumbered by significant market imperfections, farming decisions may partly be motivated by nutritional considerations, in addition to income and risk factors. These imperfections create the potential for farm assets to have direct dietary impacts on nutrition in addition to any indirect effects via income. We test this hypothesis for the dairy sector in rural Ethiopia, a context in which markets are very thin, own-consumption shares are very high, and milk is an important source of animal-based proteins and micronutrients for young children. We find that cow ownership raises children's milk consumption, increases linear growth, and reduces stunting in children by seven to nine percentage points. However, we also find that the direct nutritional impacts of household cow ownership are less important where there is good access to local markets, suggesting that market development can substitute for household cow ownership.
\end{abstract}

Key words: Child nutrition, stunting, dairy production, Ethiopia. 


\section{INTRODUCTION}

While it is intuitively plausible that agricultural development is an important driver of nutritional change in the poorest countries, there exists relatively little evidence linking agricultural production systems to nutrition outcomes. In the least developed agricultural settings, agriculture is thought to be important because of the incompleteness of markets. If certain food items cannot be reliably purchased via the market, then farmers may choose production inputs with nutrition as one of several household objectives, including profit maximization and risk minimization. This nonseparability of production and consumption decisions also has important policy implications, since it suggests that there are means by which agricultural policy can influence nutrition beyond the standard objectives of maximizing farm income or productivity. For example, if some agricultural assets or production inputs influence nutrition more than others, there may be a case for policies that promote these assets and inputs even if their income effects are equal to less nutritionally relevant inputs.

One strong candidate for an agricultural asset/input of particular nutritional important is dairy cows. Why so?

First, without modern processing technologies, most dairy products are highly perishable. The absence of these technologies suggests that the spatial development of dairy markets will be very limited, even without particularly severe infrastructural bottlenecks.

Second, milk is a source of animal-based proteins for young children (and for many mothers), as well as essential amino acids and other micronutrients such as iron, zinc, vitamin $A$ and calcium. Thus, the biomedical evidence suggests that milk consumption ought to have a relatively strong marginal effect on child nutrition in early life, particularly in the period 6 to 24 months of age when children are no longer exclusively breastfed and physical growth potential is high (Bhutta et al. 2013). Mølgaard et al., (2011), for example, write that "Observational and intervention studies show that cow's milk most likely has a positive influence on growth in children . . . through a stimulation of insulin-like growth factors". ${ }^{1}$ Many other studies also find evidence of milk and other animal sourced foods having a positive influence on linear growth and other nutrition outcomes (Marquis, et al. 1997, McLean, et al. 2007, Murphy and Allen 2003, Neumann, Harris, and Rogers 2002, Randolph, et al. 2007). Empirically, recent reviews of milk interventions in developing countries (lannotti et al. 2013; de Beer 2012) find significant effects on linear growth and other nutrition outcomes, although the majority of interventions reviewed were consumption-based (for example, school feeding programs) rather than production-based.

Third, relative to other micronutrient-rich foods (particularly animal-sourced foods), milk is consumed in relative abundance in many poor countries and is generally one of the largest sources of animal-based proteins in diets in these countries.

Fourth, relative to some other solid foods, milk and milk-based products are easily consumed and digested by small children.

Finally, there may be gender dimensions of milk that render it advantageous for nutrition. Milk involves little preparation, which reduces the time required for preparation, generally by mothers. ${ }^{2}$ And small-scale dairy production is often managed by women, who are often thought to manage household resources in a more nutritionally optimal way than men.

In this paper we test the importance of cow ownership for nutrition in the very pertinent context of rural Ethiopia. Cattle play an important and complex role in the rural Ethiopian economy. Ethiopia has the largest numbers of cattle in Africa. The Ethiopian highlands - home to around 50 million people - are more dependent on the ox-plow production system than any other major African region ${ }^{3}$. Cattle are obviously the predominant source of dairy products, but also meat. Moreover, the Ethiopian lowlands are predominantly pastoralist and agro-pastoralist agricultural systems in which cattle products are still the dominant source of both income and consumption. Nationally, milk accounts for around 30 percent of animal-sourced protein intake (FAO 2013) and 66 percent of the sheer weight of animal-based food intake.

Yet despite its potential for nutritional impact, Ethiopia's milk sector is highly underdeveloped. On the production side, milk yields are a fraction of their potential (and even of those in neighboring Kenya) because of the low use of improved breeds and poor management practices (Gebremariam et al. 2010). On the marketing side, the sluggish

\footnotetext{
${ }^{1}$ The biological mechanisms underlying this are not fully understood. Cow's milk contains insulin-like growth factor I (IGF-I) which plays a key role in growth in early life. However, it is not clear if it is the presence of IGF-I in milk, or whether compounds in milk stimulate human production of IGF-I (Hoppe et al, 2004; Hoppe et al, 2006).

2 The care of dairy cows is often the task of women in farming households, which may enable mothers to better regulate milk production and its consumption by young children in the household.

${ }^{3}$ Cattle are also an important stock of wealth and, potentially, insurance.
} 
development of cities (only 20 percent of Ethiopia's population is urban) has long constrained the demand for processed milk. Domestically produced processed and packaged milk products emerged at scale only a decade or so ago in Ethiopia, and long life milk was produced by an Ethiopian firm for the first time in 2013. In rural areas, the markets for milk remain highly incomplete: around 85 percent of all milk produced by households is consumed within the house, while 8 percent is processed into products with longer shelf life, such as butter, and just 7 percent is sold (MoARD 2007). ${ }^{4}$ This would suggest that the availability of milk at the household level will have a direct effect on feeding practices for pre-school children and on their linear growth (Key, Sadoulet, et al. 2000).

In the Ethiopian context the hypothesis that cow ownership is an important determinant of milk consumption and linear growth is therefore a strong one. Despite this, there is little previous work exploring this question. ${ }^{5}$ Research on other countries, including other east African countries such as Kenya (Hoorweg, Leegwater and Veerman 2000, Nicholson, et al. 2003), Rwanda (Pimkina et al. 2013) and Uganda (Vella, et al. 1995), provides a basis for linking dairy farming with nutrition outcomes. One analysis of a dairy intervention in Ethiopia did show gains in income, household food expenditures, and energy intakes (Ahmed, Jabbar, and Ehui 2000), but did not measure nutrition outcomes.

In this paper we test this hypothesis using a recent survey of households in 305 higher potential villages in the Ethiopian highlands. We begin with a very simple model where parents maximize a utility function that includes the nutritional status of their children, subject to income and time constraints, the production of nutritional status and household preferences (Section 2). In the presence of complete markets, specific agricultural assets only influence nutrition outcomes via their impact on household income. However, with incomplete markets, product-specific agricultural assets, such as cows, can become directly important for nutrient intake and linear growth. We then test this model using recent data from the Agricultural Growth Program Survey (AGPS) of 2011 (Section 3). Descriptively the data confirm both very high rates of stunting and the tremendous lack of dietary diversity in Ethiopia, although milk products are easily the most frequently consumed source of animal proteins for young children. We then provide some basic empirical tests of the associations between cow ownership, milk consumption of under-2s, and child anthropometric outcomes (Section 4), before turning to some important sensitivity tests (Section 5), and some potential policy implications of our results (Section 6).

We find strong empirical support for the hypothesis that cow ownership has a large and positive impact on both the milk consumption and linear growth of young children. While the statistical significance of our findings may not be surprising (particularly with regard to milk consumption), the magnitude of the estimated impacts is striking. In our most parsimonious specifications, household ownership of just a single cow predicts an increase in HAZ scores of anywhere between 0.25 and 0.47 standard deviations. These are large marginal effect by the standard of nutrition regressions, and we find similarly large reductions in the probability of stunting, which is reduced by anywhere between 6 to 13 percent. These estimates are marginally affected by the addition of other assets to the regressions, but not by income variables or community characteristics. However, the more substantive finding from our sensitivity analyses pertains to the addition of market level indicators of market access and cattle ownership. With regard to the former, we find that in the relatively few villages that have a sizeable market within their village, household cow ownership has no impact on linear growth. Similarly, high levels of village cow ownership have positive effects on milk consumption and linear growth, and somewhat reduce the marginal effects of household cow ownership. Thus we find strong support for the long run role of market development in reducing the short term necessity of cattle ownership for children's milk consumption and growth trajectories. This is clearly a finding of potential significance in the context of the current close attention in global, regional, and national development dialogues to better leveraging the nutritional impact of agricultural interventions.

\section{THEORETICAL MODEL}

We adapt the standard agricultural household model to consider dimensions of nutrition - both intake of foods and anthropometric status - under complete and missing markets. Early work in the vein is found in Singh, Squire and Strauss (1986) with the implications for nutrient intake and anthropometric outcomes worked out in Behrman and

\footnotetext{
${ }^{4} \mathrm{~A}$ much earlier study of dairy producers around Addis Ababa in the mid-1980s found large discrepancies in the prices received by milk producing households, which the authors attributed to information asymmetries and transport costs (Staal, Delgado and Nicholson 1997).

${ }^{5}$ Sadler and Catley (2009) provide a qualitative discussion in the context of pastoral areas in Ethiopia.
} 
Deolalikar (1988). ${ }^{6}$ We provide a simplified version of their work here to motivate the econometric models we will estimate. $^{7}$

We conceptualize the household decision making process as one where parents are concerned about the nutritional status of pre-school children $\left(\mathrm{H}_{c}\right)$ and their nutrient intakes $\left(\mathrm{N}_{\mathrm{c}}\right)$. Our primary interest is in $\mathrm{H}_{c}$ and $\mathrm{N}_{c}$ and so we aggregate other possible arguments in the welfare function into consumption of all other goods $\left(X_{c, n c}\right)$ by children (c) and all other household members (nc) and leisure $\left(\ell_{c}, n c\right)$. In countries like Ethiopia, marked regional differences in characteristics such as ethnicity and religion will lead to differences in consumption patterns (for example, neither Orthodox Christians nor Muslims consume pork) and so we add $\zeta$ to capture these taste norms. We write the household welfare function as:

$U=U\left(H_{c}, N_{c}, X_{c}, n c, l_{c}, n c ; \zeta\right), c=1, \ldots C ; n_{c}=1, \ldots N_{c}$

The welfare function is twice differentiable smooth. First derivatives are assumed to be positive with respect to all arguments; household welfare increases with increases in nutritional status and nutrient intake. It is maximized subject to production functions for nutritional status, income, as well as time and budget constraints. Nutritional status is produced by combining nutrient intake with time ( $\mathrm{T}_{\mathrm{PCG}}$ ) spent by the primary care giver (usually, but not always, the mother) looking after the child, knowledge of good care practices (KCARE), the subset of all other goods apart from nutrient intake (such as health care) that affect nutritional status, genetic endowments $\left(\eta_{c}\right)$ and locational characteristics (such as the prevalence of disease; access to information about good child care practices) that affect nutritional status $(Z)$.

$H_{c}=H\left(N_{c}, T_{P C G}, X_{c}, n c, K^{C A R E}, \eta_{c}, Z\right), c=1, \ldots C$

We assume that the household produces agricultural commodities $(A A)$ using a unique capital good $\left(K^{A}\right)$ for each, household knowledge of good farming practices (KFARM), and labor supplied by non-preschool household members $\left(T A_{n c}\right)$.

$Y^{A}=Y\left(K^{A}, K^{F A R M}, T^{A}{ }_{n c}\right), A=1, \ldots, A A$

For simplicity, we assume that there is no use of purchased inputs or hired labor; this assumption is easily relaxed but doing so will not fundamentally change the results we obtain. We also assume no lump sum transfers. Non-preschool household members can also engage in off-farm labor $\left(T_{n c}\right)$ at exogenous wage $w$, so hereafter we denote the exogenous prices of agricultural goods produced by the household as $\left(\mathrm{P}^{\mathrm{A}}\right)$, total income $\left(\mathrm{Y}^{\mathrm{T}}\right)$ is:

$Y^{\top}=P^{A} \cdot Y^{A}+w \cdot T_{n c} \quad, A=1, \ldots 2$

And the budget constraint can be written as:

$Y^{\top}=\sum_{c=1} c P^{N} \cdot \mathbf{N}_{\mathbf{c}}+\mathbf{P}^{\mathrm{X}} \cdot \mathbf{X}_{\mathbf{c}, \mathbf{n c}}$

where the P's are nutrients $\left(\mathrm{P}^{\mathrm{N}}\right)$ and all other goods $\mathrm{P}^{\mathrm{x}}$ and vectors are denoted by boldface. Finally, the time constraint for the household is:

$T=\sum n_{c=1} N C T_{n C}+T_{P C G}$

Under the assumption of complete markets for all inputs and outputs, constrained maximization of (1) subject to (2), (3), (5) and (6) leads to demand functions of the following form:

$\mathrm{V}=\mathrm{v}\left(\mathrm{K}^{\mathrm{CARE}}, \eta_{\mathrm{c}}, \mathrm{Z}, \zeta, w, \mathbf{P}^{\mathrm{A}}, \mathbf{P}^{\mathrm{N}}, \mathbf{P}^{\mathrm{X}}, \mathrm{Y}^{\mathrm{T}}\right)$

Where

$V=\left(H_{c}, N_{c}\right), c=1, \ldots C$

As stressed by Singh, Squire and Strauss (1986), under the strong assumptions of complete markets and exogenous wages and prices, the level of income, but not the composition or source of income, affects demands for nutrients and nutritional status (Strauss (1986) provides an example of this approach). In the Ethiopian context, a Birr is a Birr no matter whether it originates from crop production, livestock or any other source. However, these assumptions can break down for a variety of reasons; for example, productivity, and therefore wages, may depend on nutrient intake (Strauss and Thomas, 1995) or transaction costs for market interactions may be prohibitively high (de Janvry, Fafchamps and Sadoulet 1991). In the case we consider here, missing or incomplete markets is certainly a natural assumption to begin with. Rural Ethiopia lacks the technological capacity to render milk a non-perishable

\footnotetext{
${ }^{6}$ For a recent discussion, with new extensions, see LaFave and Thomas (2012).

7 Specifically, we assume a one period model with no lump sum transfers, no inputs into production apart from labor and capital that wages and labor supply are not functions of nutrient intake and that there is no intra-household bargaining. Given the focus of our paper, relaxing these assumptions will not affect our approach.
} 
good. This characteristic, along with other value chain bottlenecks (particularly infrastructure), means that the spatial integration of milk markets is very limited. Under the assumption of missing markets for milk, demand functions take the following forms:

$\mathrm{V}=\mathrm{v}\left(\mathrm{K}^{\mathrm{CARE}}, \eta_{\mathrm{c}}, Z, \zeta, w, \mathbf{P}^{\mathrm{A}}, \mathbf{P}^{\mathrm{N}}, \mathbf{P}^{\mathrm{X}}, \mathrm{K}^{\mathrm{A}}, \mathrm{K}^{\mathrm{FARM}}\right)$

where the key difference between equations (7) and (8) is the substitution of farm income by farm capital. Of particular interest is product-specific capital, which in the context of milk production is ownership of female cattle.

Before continuing, we note an important concern. If we were to model the determinants of the portfolio of household assets, KFARM and V are both outcome variables. Indeed, the case of cattle presents a complex choice in household decision-making because of several other functions that cattle serve in addition to dairy production (particularly land preparation, but also transport services, as well as savings, insurance and collateral), and because cattle ownership itself may depend on household resources, most notably sufficient access to grazing land. These constraints potentially pose an endogeneity problem in that any observed association between cattle ownership and nutrition outcomes may in fact represent other factors, such as land constraints (largely observable), exposure to shocks (partly observable) or farm management abilities (largely unobservable). These considerations motivate many of the sensitivity analyses presented below, though we are careful to emphasize that our ability to completely eliminate endogeneity concerns is limited, particularly with cross-sectional data.

\section{DATA}

Our data are drawn from a household survey intended to be the baseline for an evaluation of the government of Ethiopia's Agricultural Growth Program (AGP). ${ }^{8}$ The AGP targets 83 woredas ${ }^{9}$ in the four highland regions of Ethiopia - Amhara, Oromiya, SNNP, and Tigray - that are perceived to have relatively high growth potential based on their access to markets, natural resource endowments, mean rainfall levels, potential for small scale irrigation, and availability of agricultural service providers. The AGP survey (hereafter AGPS) collected data in 61 of these woredas, as well as in 32 non-AGP woredas with similar characteristics during July $2011 .{ }^{10}$ Five enumeration areas (EAs) were randomly sampled within each woreda and 26 households were sampled within each EA, yielding a target sample of 7,930 households. Note that, given the objective of the AGP to meet certain historically under-served groups, the composition of the sample within each EA reflects programmatic emphasis given to female headed and youth headed households. ${ }^{11}$

Figure 1 shows where these woredas are located (dark circles) as well as their proximity to market towns (light circles). The figure also notes population density with darker shades representing higher density areas. We denote this feature in the graph since land constraints will typically be an important determinant of cattle ownership, as previous reviews of the Ethiopian livestock sector have stressed.

In terms of survey content, the AGPS collected a rich array of data on agricultural inputs and outputs by plot level, detailed livestock ownership, farm size, family and hired labor, and marketing information (household consumption, sales, and so on). And while nutrition outcomes are not a central focus of the program itself, the growing interest in seeing agricultural interventions have an impact on nutrition outcomes means that the AGP contains the requisite information on child anthropometrics for children under the age of 5 , as well as consumption frequency indicators for children under the age of 2 years. The food item consumption module contains yes/no questions on whether a child has consumed a specific type of food item over the previous week (e.g. milk, green vegetables, cereals, pulses, and so on), and if so, how many days in the previous week. Thus, the module closely mirrors the kind of data collected in World Food Programme surveys and used for constructing the WFP's Food Consumption Score (FCS) (see Wiesmann, et al. (2009) for a study validating these indicators).

\footnotetext{
${ }^{8}$ Increased smallholder productivity and value-addition in the agricultural sector are core elements of the Ethiopian Government's approach to poverty reduction. The AGP began in the second half of 2011 . It is planned as a five-year program that increase agricultural productivity and market access for key crop and livestock products.

${ }^{9} \mathrm{~A}$ woreda is the administrative unit below a region and is loosely akin to a district or county.

${ }^{10}$ One issue that this paper is not able to address is seasonality of milk consumption. The AGP baseline was conducted in July of 2011 . In much of the country July falls in the middle of the main rainy season, meaning that fodder availability and milk yields may be higher than at other times of the year. In principle, linear growth reflect cumulative nutrition, meaning that we would ideally like to measure the impacts of seasonal shortfalls in milk consumption, but unfortunately this is beyond the scope of the present paper.

11 The EA level sample is divided into female and male headed households and each group further divided into youth headed and mature headed households. Thus the EA sample is divided into a total of 4 age-gender groups. Consequently, the AGP baseline slightly oversamples households headed by both young and mature females relative to their share implied by Census 2007 . In contrast, mature male headed households are slightly under-sampled.
} 
Figure 1-AGP enumeration areas (dark circles), major markets (light circles), and woreda level population density

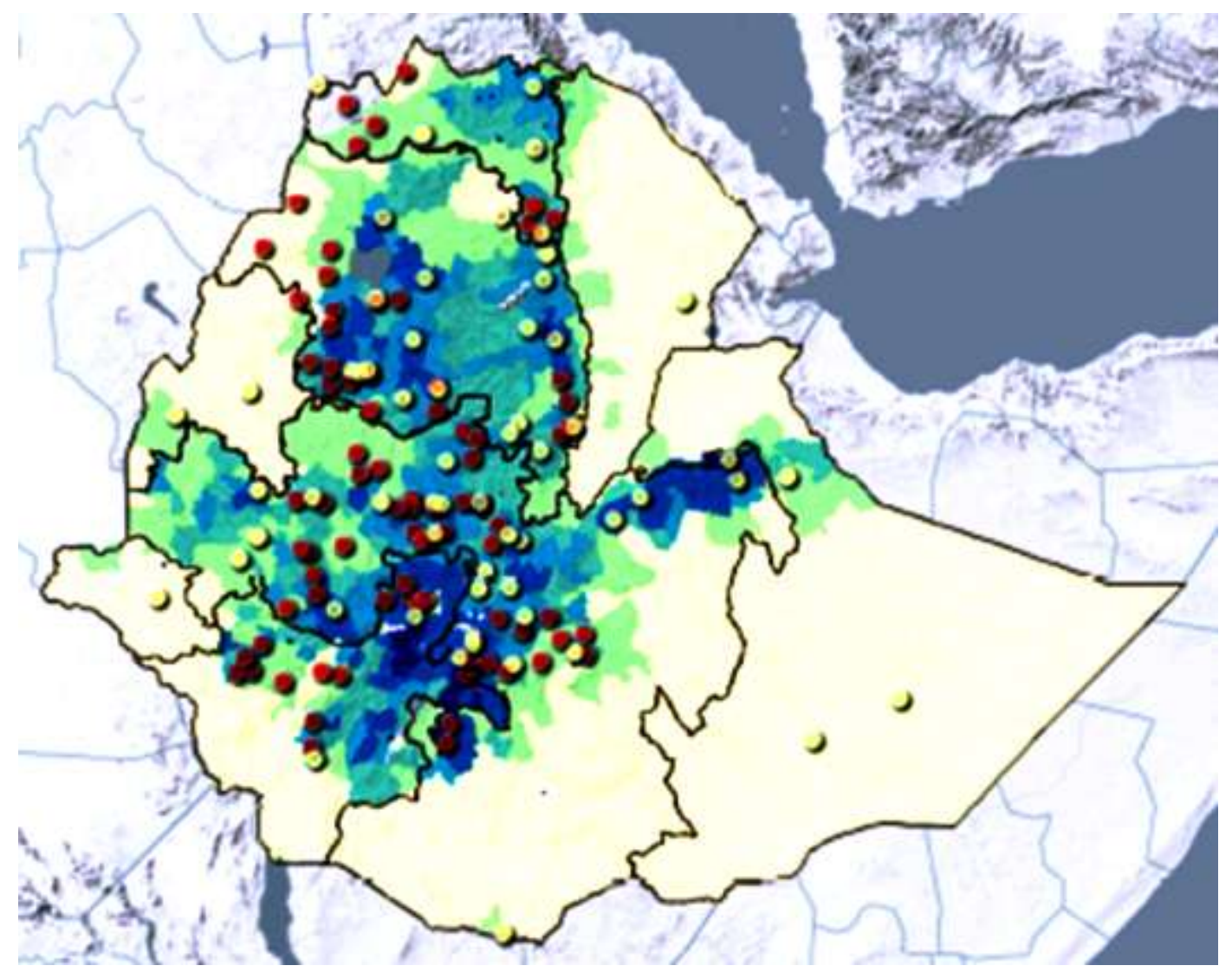

Source: http://www.gafspfund.org/content/ethiopia. Market towns (light circles) are from FEWSNET, and population density at the woreda level is from the 2007 National Census of Ethiopia.

Notes: Population density categories (in persons per square kilometer) from lightest to darkest are 0-31, 31-101, 101-139, 139-195, 195-537, 537 and above.

Table 1 provides descriptive statistics for the key variables used in this study. The anthropometric indicators show that stunting (the main nutrition variable of interest) is very high in this sample (47 percent) and approximately equal to the rural average for all Ethiopia in the Demographic Health Survey (DHS) of 2010-11. With regard to dietary indicators, we report those items pertaining to consumption of protein-rich food items in order to demonstrate the importance of milk and milk-based products (principally cheese and yoghurt) for protein consumption, as well as consumption of fatty acids and micronutrients, such as iron. Around one quarter of children consumed milk in the last seven days, and 18 percent consumed cheese or yoghurt. Combined, around 35 percent of children aged between six and 24 months consumed at least one dairy product in the last week. This is substantially higher than the percentages consuming pulses (23 percent), eggs (18 percent), or meat (10 percent). Among those consuming the respective food types, milk is also consumed the most frequently (on average on 5.44 of the past seven days), followed by pulses ( 4.28 days), cheese and yoghurt (4.12 days), while eggs and meat and are consumed quite infrequently (just over two days). Thus, there is strong evidence that milk is one of the most important sources of protein for young children, in what is otherwise a highly undiversified diet.

Next, we report descriptives for some basic assets of interest. In the Ethiopian highlands, farm sizes are generally very small. The estimate of average area cultivated from the AGPS is around 1.5 hectares, though about half of all households operate less than one hectare, suggesting that land is a major constraint. Land is also likely to be one constraint on cattle ownership, especially in villages with little communal grazing land or other feed sources. About 64 percent of households own at least one cow that could potentially produce dairy products. Average cow ownership is 1.45 cows, but this is raised by the presence of a few large ranching operations (median cow ownership is one). Finally, crop income is the main source of income for most households, and relatively few farmers in this nonpastoralist survey sample specialize in livestock production. This is consistent with production being heavily focused on satisfying household consumption needs. 
Table 1-Descriptive statistics for key variables

\begin{tabular}{|c|c|c|c|}
\hline Variable & Obs & Mean & Std. Dev. \\
\hline \multicolumn{4}{|c|}{ Anthropometric indicators for children aged 6 months to 5 years } \\
\hline HAZ, children aged six months to five years & 4479 & -1.74 & 1.72 \\
\hline Stunted & 4479 & 0.47 & 0.49 \\
\hline \multicolumn{4}{|c|}{ Dietary indicators for children aged 6 to 24 months (whether, and number of days) } \\
\hline Milk last 7 days: Yes=1 & 2798 & 0.25 & 0.44 \\
\hline \# of days consumed milk & 2798 & 5.44 & 2.00 \\
\hline Cheese/yoghurt last 7 days: Yes=1 & 2789 & 0.18 & 0.39 \\
\hline \# of days consumed cheese/yoghurt & 2789 & 4.12 & 2.16 \\
\hline Meat last 7 days: Yes $=1$ & 2790 & 0.10 & 0.28 \\
\hline \# of days consumed meat & 2790 & 2.12 & 1.40 \\
\hline Eggs last 7 days: $Y e s=1$ & 2790 & 0.18 & 0.39 \\
\hline \# of days consumed eggs & 2790 & 2.62 & 1.54 \\
\hline Pulses last 7 days: & 2785 & 0.23 & 0.42 \\
\hline \# of days consumed pulses & 2785 & 4.28 & 2.24 \\
\hline \multicolumn{4}{|c|}{ Household income and assets } \\
\hline Cultivated land (ha) & 4908 & 1.49 & 1.53 \\
\hline Crop income (birr) & 4750 & 12290 & 31108 \\
\hline Livestock income (birr) & 4697 & 1377 & 3204 \\
\hline Household owns at least one cow & 4876 & 0.64 & 0.48 \\
\hline Number of cows owned & 4697 & 1.45 & 8.45 \\
\hline \multicolumn{4}{|c|}{ Community characteristics } \\
\hline Cows per household, EA average & 4697 & 1.33 & 1.42 \\
\hline Length of growing period (days) & 4863 & 233 & 76 \\
\hline Mean elevation & 4863 & 1983 & 499 \\
\hline Mean slope & 4863 & 16.07 & 6.68 \\
\hline Village has electricity? & 4845 & 0.17 & 0.37 \\
\hline Village has piped water? & 4863 & 0.32 & 0.47 \\
\hline Village has cell phone coverage? & 4863 & 0.71 & 0.45 \\
\hline Distance $(\mathrm{km})$ to nearest market town & 4863 & 12.32 & 11.20 \\
\hline Travel time (hours) to nearest $50 \mathrm{~K}$ city & 4863 & 5.07 & 3.25 \\
\hline
\end{tabular}

Source: Authors' calculations from AGPS 2011.

The remaining community characteristics are only indirectly relevant. Agroecological variables show that, despite the label "high potential areas", the AGP villages are highly variable in terms of length of growing period, elevation, and slope. Moreover, access to infrastructure is quite poor. The average travel time to a 50,000 person city is around five hours, and electricity and piped water remain relatively rare.

\section{BASIC RESULTS}

We begin with an estimable specification of (8) for the two basic outcomes we consider in this paper: intake of milk for children under two years of age and anthropometric status. Sensitivity results will follow in the next section. Endowments $\left(\eta_{c}\right)$ are measured as child sex and age (measured in months), reflecting the idea that growth potential varies by age and sex. Knowledge of good care practices (KCARE) is measured by care givers education and age. Characteristics of the head (age, education, sex) capture knowledge of good farming practices (KFAR) as well as reflecting taste shifters $(\zeta)$. We use region dummy variables to capture all prices $\left(w, \mathbf{P}^{\mathbf{A}}, \mathbf{P}^{\mathbf{N}}, \mathbf{P}^{\mathbf{X}}\right)$ as well as the health environment $(Z)$. Finally, we represent capital goods for agriculture $\left(K^{A}\right)$ by land operated by the household for cultivation and the ownership of at least one cow. Standard errors are clustered at the woreda level. Our basic results are reported in Tables 2, 3 and 4.

Table 2 shows the relationship between cow ownership and the likelihood of a child aged 6 to 24 months consuming milk in the seven days prior to the survey and the number of days in the last seven days that milk was consumed. Column (1), estimated using a probit, shows that cow ownership increases the likelihood that milk was consumed by 22.5 percentage points. Column (2), estimated using OLS, shows that cow ownership increases the frequency of 
milk consumption by 1.2 days per week. Both results are statistically significant at the $1 \%$ level. These results are robust to alternative estimators. Estimating column (1) using a linear probability model and estimating column (2) with a count model, such as a Poisson model, gives similar results. Note, also, that we find this relationship for both boys and girls and that the magnitudes of these effects are similar when we disaggregate by the sex of the head of the household.

\section{Table 2- Milk consumption by children aged 6 to 24 months}

(1)

Marginal effect on any milk consumption in last seven days

Household owns cow
(2)

Number of days milk consumed in last seven days

$1.263 * * *$

(0.140)

$\begin{array}{lr}(0.024) & (0.140) \\ 1,555 & 1,554\end{array}$

Observations

1,555

1,554

Notes: Standard errors, in parentheses, clustered at woreda level. ${ }^{* *},{ }^{* *},{ }^{*}$, denote statistical significance at the $1 \%, 5 \%$ and $10 \%$ levels, respectively. Column (1) estimated using a probit; column (2) estimated using ordinary least squares. Controls included but not reported are: child's sex; log age (months); maternal age and whether she had any formal schooling; age and sex of the household head and whether the head has had any formal schooling; land area cultivated; and regional dummy variables. The sample pertains only to children aged 6-24 months.

Table 3 reports the relationship between cow ownership and child height, expressed in terms of $z$ scores and also whether the child is stunted. As noted above, we have height data for all children aged 0-59 months. In our initial specifications, we disaggregate these data into three age groups: 0-6 months; 6-24 months; and 24-59 months. There is no effect for children in the age categories 0-6 months or 24-59 months. For children 6-24 months, cow ownership raises HAZ by 0.2 standard deviations (SDs) and reduces the likelihood of stunting by 5.5 percentage points. These effects are not very precisely measured, being statistically significant only at the 10 percent level. However, there are also indications of heterogeneity within the 6-24 month age range. Between 12-24 months and especially 12-18 months, the effects on z scores are large, 0.32 and 0.47 SDs, respectively, and both estimates are more precisely estimated (both are significant at the 1 percent level). Furthermore, cow ownership reduces stunting by 9.9 and 13.3 percentage points for these age groups, respectively. These results are consistent with the biomedical literature referred to our introductory section. By contrast, we observed no impacts of cow ownership on child weight as measured by child weight-for-height $z$ scores (Table 4). ${ }^{12}$

Table 3- Association between child height and ownership of cows by child age groups

\begin{tabular}{|c|c|c|c|c|c|c|c|}
\hline & (1) & $(2)$ & (3) & (4) & (5) & (6) & (7) \\
\hline & \multicolumn{7}{|c|}{ Age range (months) } \\
\hline & $0-6$ & $6-24$ & $24-60$ & $6-12$ & $12-18$ & $18-24$ & $12-24$ \\
\hline & \multicolumn{7}{|c|}{ Outcome variable: Height-for-age z score } \\
\hline \multirow[t]{3}{*}{ Household owns cow } & 0.452 & $0.214^{*}$ & 0.063 & $0.251^{*}$ & $0.471 * * *$ & 0.025 & $0.324 * * *$ \\
\hline & $(0.659)$ & $(0.112)$ & $(0.081)$ & $(0.135)$ & $(0.153)$ & $(0.164)$ & $(0.117)$ \\
\hline & \multicolumn{7}{|c|}{ Outcome variable: Child is stunted } \\
\hline \multirow[t]{2}{*}{ Household owns cow } & 0.088 & $-0.055^{*}$ & -0.018 & $-0.058 *$ & $-0.133 * * *$ & -0.041 & $-0.099 * * *$ \\
\hline & $(0.116)$ & $(0.028)$ & $(0.020)$ & $(0.034)$ & $(0.036)$ & $(0.047)$ & $(0.028)$ \\
\hline Observations & 59 & 1,590 & 3,092 & 1,124 & 642 & 586 & 1,108 \\
\hline
\end{tabular}

Notes: Standard errors, in parentheses, clustered at woreda level. ${ }^{\star \star *},{ }^{* \star},{ }^{*}$, denote statistical significance at the $1 \%, 5 \%$ and $10 \%$ levels respectively. See Table 2 for list of controls.

Table 4-Association between child weight and ownership of cows by child age groups

\begin{tabular}{lcccccccc}
\hline & $(1)$ & $(2)$ & $(3)$ & \multicolumn{7}{c}{$(4)$} & $(5)$ & $(6)$ & $(7)$ \\
& & & \multicolumn{7}{c}{ Age range (months) } & & \\
& $0-6$ & $6-24$ & $24-60$ & $6-12$ & $12-18$ & $18-24$ & $12-24$ \\
Household owns cow & -0.286 & 0.077 & -0.009 & 0.114 & 0.071 & 0.076 & 0.027 \\
& $(0.308)$ & $(0.099)$ & $(0.068)$ & $(0.119)$ & $(0.133)$ & $(0.156)$ & $(0.105)$ \\
Observations & 186 & 1,580 & 3,049 & 1,109 & 637 & 598 & 1,108 \\
\hline
\end{tabular}

Notes: Standard errors, in parentheses, clustered at woreda level. ${ }^{* * *},{ }^{* *},{ }^{*}$, denote statistical significance at the $1 \%, 5 \%$ and $10 \%$ levels respectively. See Table 2 for list of controls.

${ }^{12}$ There is no impact on wasting for children 6-24 months; for brevity, these results are omitted but are available on request. 
One potential flaw in the argument that household cow ownership matters for milk consumption and stunting levels among children aged 6 to 24 months is if local markets are sufficiently well developed to cater to household demand for milk purchases. To test this idea, we disaggregate our sample into villages that report a food market within the village itself, and those that do not (Table 5). ${ }^{13}$ We note, however, that very few AGPS villages report that the market exists in the village itself. Nevertheless, there are some indications that market access matters. In the first column, we observe a positive and highly significant impact of cow ownership on milk consumption in the market village sample (0.189), and this point estimate is not significantly different or substantially lower than the non-market village sample (0.222). However, for the remaining two dependent variables we do see substantially different effects. For the number of days that milk was consumed, the point estimate for market villages is 0.70 days and significant at the $5 \%$ level (but rather imprecisely estimated), while in the non-market villages the marginal impact is a much higher 1.27 days. The imprecision of the estimates (which may be related to the small sample of market villages) means that these marginal effects are not significantly different from each other, ${ }^{14}$ but the final set of results lends more weight to the role of local markets. In the market village sample we find no significant impact of cow ownership on HAZ (in fact, the point estimate is even negative, but highly insignificant). In contrast, the non-market village sample displays a large and significant marginal impact of 0.393 SDs, consistent with the results above. Potentially, the results in Table 5 have strong policy implications if there is a role for external interventions to develop local markets. We will return to this issue in our concluding section.

\section{Table 5- Milk consumption, child height and cow ownership by access to food markets}

\begin{tabular}{|c|c|c|c|c|c|c|}
\hline & \multicolumn{3}{|c|}{ Food market in village } & \multicolumn{3}{|c|}{ No food market in village } \\
\hline & (1) & (2) & (3) & (4) & (5) & (6) \\
\hline & $\begin{array}{l}\text { Marginal effect } \\
\text { on any milk } \\
\text { consumption }\end{array}$ & $\begin{array}{l}\text { \# days milk } \\
\text { consumed }\end{array}$ & $\mathrm{HAZ}$ & $\begin{array}{c}\text { Marginal effect } \\
\text { on any milk } \\
\text { consumption }\end{array}$ & $\begin{array}{l}\text { \# days milk } \\
\text { consumed }\end{array}$ & HAZ \\
\hline \multirow[t]{2}{*}{ Household owns cow } & $0.189 * * *$ & $0.702 * *$ & -0.185 & $0.222 * * *$ & $1.275^{* * *}$ & $0.393 * *$ \\
\hline & $(0.050)$ & (0.309) & $(0.447)$ & $(0.026)$ & $(0.152)$ & $(0.133)$ \\
\hline Observations & 153 & 151 & 117 & 1,402 & 1,393 & 991 \\
\hline
\end{tabular}

Notes: Standard errors, in parentheses, clustered at woreda level. ${ }^{* * *},{ }^{* *},{ }^{*}$, denote statistical significance at the $1 \%, 5 \%$ and $10 \%$ levels respectively. See Table 2 for list of controls.

\section{ROBUSTNESS CHECKS AND EXTENSIONS}

In this section we engage in a series of robustness checks and extensions designed to establish the extent to which the results presented in the previous section stand up to alternative specifications and to a more confident causal interpretation.

\section{Testing the impacts of cow ownership at the village level}

One might expect that households in a village can very informally trade or barter milk products even in the absence of a reported village market. Such informal trading possibilities might suggest that it is not household cow ownership that matters, but village ownership. To test this notion we add the log of average cows per household at the village level to the regressions above. As expected, this variable shares a reasonably high correlation with the household level indicator of owning at least one cow, of around 0.20. However, adding EA level cow ownership to the models above does little to change the results. In the first and second columns of Table 6 we see that the marginal effect of household cow ownership on any milk consumption drops very slightly, although the EA cow ownership is significant at the $5 \%$ level, but with a reasonably small marginal effect of 0.058 . In the next two columns we see an analogous pattern of results for the number of days of milk consumption. The marginal impact of the household cow ownership indicator drops from 1.26 to 1.10, and EA level ownership again has a highly significant impact on milk consumption days, implying that a doubling of cow ownership at the EA level would increase milk consumption by 0.36 days. In the last two columns, the marginal impact of EA cow ownership on child HAZs is not quite significant at the $10 \%$ level, although the marginal impact of household cow ownership does decrease from 0.32 to 0.23 SDs when

\footnotetext{
${ }^{13}$ Given the highly perishable nature of milk, we believe that most villages would require a market in the village itself in order to purchase milk on a regular basis.

${ }^{14}$ Consistent with this, including a term interacting owning a cow with distance to market produces correctly signed parameter estimates but these interaction terms are not statistically significant.
} 
the village indicator is added to the model. However, the impact of cow ownership on stunting is robust to the inclusion of EA cow ownership (results available on request). Overall, then, there is substantial support for the "village trade" hypothesis, although cow ownership at the household level still seems to be the more important correlate of milk consumption and child height. This suggests the existence of incomplete local markets. One explanation may be that cow ownership and milk yields are so low that households have little surplus production with which to trade.

Table 6- Milk consumption, child height, and cow ownership, with controls for locality-level cow ownership

(1) (2)

Marginal effect Marginal effect

on any milk on any milk

consumption consumption

Household owns cow

$0.225^{* * *}$

(0.024)

Village cows ${ }^{\mathrm{a}}$

$0.204^{* * *}$

(0.024)

$0.058^{* *}$

(0.028)

1,488

Observations

1,555
(3)

\# days milk \# days milk con-

consumed

$1.263^{* * *}$

(0.140)

-

$1,554 \quad 1,476$
(4)

sumed

$1.108^{* * *}$

(0.126)

$0.362^{* * *}$

(0.152)
(5)

(6)

HAZ

$(12-24 m)$

$0.324^{* * *}$

(0.117)

0.22

(0.150)

1,108

1,063

Notes: Standard errors, in parentheses, clustered at woreda level. ${ }^{* * *},{ }^{* *},{ }^{*}$, denote statistical significance at the $1 \%, 5 \%$ and $10 \%$ levels respectively. See Table 2 for list of controls.

a. Village cows is the log of mean cows per households at the village level, which we take as a proxy for the thickness of local dairy markets.

\section{Are the effects of cow ownership a specific nutritional effect or a general asset effect?}

One endogeneity concern is that the observed impact of owning a cow represents a general asset effect, rather than representing a specific nutritional channel pertaining to milk consumption. One finding that makes this unlikely is the positive and significant marginal impact of milk consumption on stunting (results not shown), but a further means of corroborating the nutrition-specific effect is to see whether the likelihood of a child consuming other foods is affected by the ownership of cows. If ownership of cows is merely an income effect, and the consumption of these other foods by pre-school children is a normal good, then ownership of cows should be positively correlated with consumption of other foods. In effect, then, this is a placebo test. The results of this test are reported in Table 7. In no case do we find cow ownership to be significantly associated with more consumption of other high-value nutrientdense foods.

\section{Table 7-Does cow ownership increase the likelihood of consuming other high value foods? A placebo test}

Consumption in last seven days of ...

\begin{tabular}{|c|c|c|c|c|c|c|c|}
\hline & (1) & (2) & (3) & (4) & (5) & (6) & (7) \\
\hline & Pulses & Vegetables & $\begin{array}{l}\text { Leafy vege- } \\
\text { tables }\end{array}$ & Fruit & Meat & $\begin{array}{l}\text { Meat or- } \\
\text { gans }\end{array}$ & Eggs \\
\hline \multirow[t]{2}{*}{ HH owns cow } & 0.002 & -0.015 & 0.022 & 0.012 & 0.000 & 0.003 & 0.006 \\
\hline & $(0.027)$ & (0.019) & $(0.024)$ & (0.018) & $(0.016)$ & (0.005) & (0.023) \\
\hline Observations & 1,552 & 1,553 & 1,556 & 1,554 & 1,556 & 1,554 & 1,556 \\
\hline
\end{tabular}

Notes: Standard errors, in parentheses, clustered at woreda level. ${ }^{* *},{ }^{* *},{ }^{*}$, denote statistical significance at the $1 \%, 5 \%$ and $10 \%$ levels respectively. See Table 2 for list of controls.

Another way to test our results is just to add all available asset/income variables to the regression. In Table 8 we successively add several asset variables (number of oxen, goats, sheep, donkeys, bulls, calves, and chickens owned) ${ }^{15}$ crop and livestock income variables, and crop and livestock input expenditure variables. Adding other asset variables to the model reduces the marginal effect of cow ownership on the number of milk consumption days by about 0.25 days (from 1.26 to 1.00), but adding income variables has immaterial effects. The middle panel focuses on HAZ scores for children aged 12- 24 months, and we observe a similar pattern of lower marginal effects when the regression is loaded with asset variables (a reduction of 0.32 SDs to $0.25 \mathrm{SDs}$ ), but little effect of the income variables. This is also true when we consider stunting.

${ }^{15}$ Note that these are in addition to land which is controlled for in the basic specification. 
Table 8- Milk consumption, child height, and cow ownership, with controls for crop and livestock income

\begin{tabular}{|c|c|c|c|c|}
\hline & \multicolumn{4}{|c|}{ \# days milk consumed in last seven days } \\
\hline & (1) & (2) & (3) & (4) \\
\hline \multirow[t]{2}{*}{ Household owns cow } & $1.263^{* * *}$ & $1.005^{* * *}$ & $1.212 * * *$ & $0.983 * * *$ \\
\hline & $(0.140)$ & $(0.151)$ & $(0.140)$ & $(0.150)$ \\
\hline Other asset variables & $\mathrm{N}$ & $\mathrm{Y}$ & $\mathrm{N}$ & $\mathrm{Y}$ \\
\hline Ag income variables & $\mathrm{N}$ & $\mathrm{N}$ & $\mathrm{Y}$ & $\mathrm{Y}$ \\
\hline \multirow[t]{3}{*}{ Observations } & 1,544 & 1,544 & 1,600 & 1,529 \\
\hline & \multicolumn{4}{|c|}{$\underline{\mathrm{HAZ} \text {, children aged } 12 \text { to } 24 \text { months }}$} \\
\hline & (5) & (6) & (7) & (8) \\
\hline \multirow[t]{2}{*}{ Household owns cow } & $0.324 * * *$ & $0.249 * *$ & $0.317 * * *$ & $0.247^{*}$ \\
\hline & $(0.117)$ & $(0.125)$ & $(0.118)$ & $(0.125)$ \\
\hline Other asset variables & $\mathrm{N}$ & $\mathrm{Y}$ & $\mathrm{N}$ & $\mathrm{Y}$ \\
\hline $\mathrm{Ag}$ income variables & $\mathrm{N}$ & $\mathrm{N}$ & $\mathrm{Y}$ & $\mathrm{Y}$ \\
\hline \multirow[t]{3}{*}{ Observations } & 1,108 & 1,108 & 1,151 & 1,097 \\
\hline & \multicolumn{4}{|c|}{ Stunting, children aged 12 to 24 months } \\
\hline & (9) & (10) & $(11)$ & (12) \\
\hline \multirow[t]{2}{*}{ Household owns cow } & $-0.099 * * *$ & $-0.088 * * *$ & $-0.102 * * *$ & $-0.091 * * *$ \\
\hline & $(0.028)$ & $(0.030)$ & $(0.029)$ & $(0.030)$ \\
\hline Other asset variables & $\mathrm{N}$ & $\mathrm{Y}$ & $\mathrm{N}$ & $\mathrm{Y}$ \\
\hline Ag income variables & $\mathrm{N}$ & $\mathrm{N}$ & $\mathrm{Y}$ & $\mathrm{Y}$ \\
\hline Observations & 1,108 & 1,108 & 1,151 & 1,097 \\
\hline
\end{tabular}

Notes: Standard errors, in parentheses, clustered at woreda level. ${ }^{* * *},{ }^{* *},{ }^{*}$, denote statistical significance at the $1 \%, 5 \%$ and $10 \%$ levels respectively. See Table 2 for list of controls.

\section{Does cow ownership reflect agroecological or infrastructural conditions?}

The ownership of cows is not a random phenomenon. In addition to being a store of wealth and an agricultural asset, cattle ownership may be affected by local agroecological and infrastructural characteristics, such as the availability of feed and water, or access to markets, services, or infrastructure. Since some of these variables could conceivably have direct impacts on nutrition, as a final check we therefore include the following locality characteristics on the right hand side of our basic equations: whether the EA has electricity, piped water, an agricultural extension office, a bank or microfinance institution (MFI), cell phone signals, radio signals, and agroecological conditions, such as mean elevation, mean rainfall, and length of the growing period. Columns (1) and (2) of Table 9 repeats the results of our basic specification and the inclusion of the asset and crop income variables. Column (3) adds in these EA variables and column (4) is a woreda fixed effects specification which controls for woreda-level unobservables such as prices. For frequency of consumption and stunting, the inclusion of these variables does not affect our results. There is some diminishing of the effect on height-for-age $z$ score when we include woreda fixed effects. 


\section{\# days milk consumed in last seven days}

(1)

Household owns cow
Asset Variables
Ag income variables
EA characteristics
Zone dummy variables
Observations

Household owns cow

cousehold owns cow

Asset Variables

$\mathrm{Ag}$ income variables

EA characteristics

Zone dummies

Observations

Observations

Household owns cow

Asset Variables

$\mathrm{Ag}$ income variables

EA characteristics

Zone dummies

Observations

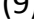

$-0.099 * * *$

(0.028)

$$
\begin{gathered}
1.263 * * * \\
(0.140)
\end{gathered}
$$

$N$
$N$
$N$
$N$
1,544

(5)

$0.324^{* * *}$

(0.117)

$N$
$N$
$N$
$N$
1,108

$\mathrm{N}$
$\mathrm{N}$
$\mathrm{N}$

1,108
(2)

$0.983 * * *$

(0.150)

Y

Y

N

$\mathrm{N}$

1,529

$\underline{\mathrm{HAZ} \text {, children } 12-24 \mathrm{~m}}$

(6)

$0.247^{*}$

(7)

(0.125)

$Y$

Y

N

$\mathrm{N}$

1,097

(0.119)

$\mathrm{Y}$

$1.289 * * *$

(0.153)

$\mathrm{Y}$

Y

Y

$\mathrm{N}$

1,528

(10)

$-0.091 * * *$

(0.030)

$\mathrm{Y}$
$\mathrm{Y}$
$\mathrm{N}$
$\mathrm{N}$

(3)
(4)

$0.818^{* * *}$

(0.151)

$\mathrm{Y}$

$\mathrm{Y}$

Y

Y

1,409

(8)

0.118

(0.142)

$Y$

Y

Y

Y

1,089

$-0.069 * * *$

(0.035)

$\mathrm{Y}$

Y

Y

$Y$

$1,097 \quad 1,100 \quad 1,089$

Notes: Standard errors, in parentheses, clustered at woreda level. ${ }^{* * *},{ }^{* *},{ }^{*}$, denote statistical significance at the $1 \%, 5 \%$ and $10 \%$ levels respectively. See Table 2 for list of controls.

\section{Are the results robust to other data, and nationally representative?}

The AGP data used above are advantageous in having detailed agricultural asset and production variables, as well as the requisite consumption and nutrition variables. However, the sampling of higher potential areas potentially raises concerns about the external validity of the results in the broader Ethiopian context. In light of that concern we therefore estimated analogous regressions using the 2000 Ethiopian Demographic Health Survey (EDHS). The advantage of the EDHS is that it is nationally representative (for both rural and urban areas), but a disadvantage is that cattle ownership is measured purely as a dummy variable for whether or not a household owns at least one cow and the survey provides less information on other agricultural assets. However, the EDHS consumption and anthropometric data are otherwise very similar to the variables used in AGP, as are many of the control variables, including an asset index and the usual child and maternal control variables. Another advantage of the EDHS is that it allows us to test the market access interaction with a different variable, whether the household lives in a farming community or a rural town. In the latter, about 25 percent of households own at least one cow.

Table 10 reports our results, using OLS regressions and a wide range of control variables, and restricting the sample to children aged 6 to 24 months, for increasing comparability to the core AGP results reported above. ${ }^{16}$ The main conclusion from Table 10 is that the AGP results are highly robust to the use of the EDHS. Cow ownership increases the probability of consuming milk on a daily basis by 28 percentage points, and the estimate is a fairly

${ }^{16}$ Note that we also ran regressions for the full sample of children aged 6 to 59 months. In contrast to our AGP results, we found that cow ownership had significant benefits for child growth across the full range of children under 5 years of age. Results are available upon request. 
precise one. For farming areas, cow ownership predicts an increase in HAZ scores of 0.23 standard deviations, and a reduction in stunting probability of around 6 points. However, cow ownership in rural towns - another definition of access to markets - seems to be far less important for growth outcomes, although the cow-town interaction terms are never statistically significant. We conjecture that the lack of statistical significance may be because the definition of rural towns encompasses agglomerations of very different sizes, economic structures, and other pertinent characteristics. Indeed, future research on these issues would benefit from more sector or product-specific definitions of "market access".

\section{Table 10- Extension of tests to the 2000 Ethiopian Demographic Health Survey (EDHS)}

\begin{tabular}{lccc}
\hline & $(1)$ & $(2)$ & $(3)$ \\
& Daily milk consumption, & HAZ, children & Stunting, children \\
children aged 12 to 24 mos. & aged 12 to 24 mos. & aged 12 to 24 mos. \\
HH owns cow ${ }^{\text {a }}$ & $0.280^{* * *}$ & $0.231^{* *}$ & $-0.058^{*}$ \\
Cow*Town dummy & $(0.023)$ & $(0.104)$ & $(0.035)$ \\
& -0.055 & -0.432 & 0.143 \\
Town dummy & $(0.117)$ & $(0.353)$ & $(0.133)$ \\
& $0.139^{*}$ & 0.06 & -0.082 \\
Asset Variables & $(0.077)$ & $(0.283)$ & $(0.097)$ \\
Maternal variables & YES & YES & YES \\
Region dummies & YES & YES & YES \\
Religion dummies & YES & YES & YES \\
Child variables & YES & YES & YES \\
Observations & YES & YES & YES \\
\hline
\end{tabular}

Notes: Regressions are OLS, and estimated using the 2000 Ethiopian Demographic Health Survey (EDHS). Though nationally representative, we use the rural and small town sample, but exclude the Somalia and Afar regions where the survey was not strictly representative. Standard errors, in parentheses, are clustered at DHS cluster level. ***, ${ }^{* \star}$, *, denote statistical significance at the $1 \%, 5 \%$ and $10 \%$ levels respectively.

\section{CONCLUSIONS}

In this paper we find strong support for the compelling hypothesis that cow ownership in underdeveloped rural settings is an important driver of the milk consumption and linear growth of young children. While these results are still qualified by potential endogeneity concerns pertaining to household and community unobservables (even after substantive sensitivity tests), particularly the non-randomness of cow ownership, we nevertheless uncover enough evidence to justify further research and policy experimentation.

On the research front, the non-experimental context of our analysis could conceivably be improved by experimental approaches (see Leroy and Frongillo (2007), Masset et al. (2012), and lannotti et al. (2013) for reviews of this relatively small literature). Both cow ownership and dairy yields are unlikely to be purely exogenous in most settings. At the same time, research should not abstract from the behavioral context of household decisions on cow ownership, particularly as cattle serve multiple and complex roles in rural settings: as tractors, as stores of wealth, and as insurance against shocks, such as crop failure.

Another important implication of our results pertains to measurement. If cow ownership (or the development of dairy markets) really is an important determinant of child nutrition, the relative neglect of agricultural indicators in standard health and nutrition surveys (such as many of the widely used Demographic Health Surveys) is surely a costly one. Cow ownership - in some settings at least - may be as important a driver of nutrition outcomes as many better known determinants. Arguably then, somewhat more detailed agricultural modules should be mainstreamed in such surveys.

On the policy front, we find indicative evidence supporting experimentation with three possible classes of intervention: (1) interventions to increase cow ownership; (2) interventions to increase dairy productivity; and (3) interventions to increase dairy market development. The choice between these interventions is fraught with potentially important tradeoffs, as well as synergies. On the one hand, our results suggest that cattle ownership at the household level might have the largest short term benefits. While cattle are not cheap, the nutritional benefits of ownership appear to be large, and cattle rearing and dairy production are common enough skills in most rural settings. 
But with continued human population growth and increased competition for feed and water resources, there are also inherent limits to cattle population growth in the resource-constrained Ethiopian highlands. Ultimately, improved productivity and marketing in the dairy sector are outcomes that are more likely to yield sustainable, long term benefits. Productivity growth is likely to be a necessary but not sufficient condition for increasing the marketable surplus. Historically, demand-side factors (low levels of income and urbanization) have been a binding constraint on the adoption of improved dairy technologies in poor countries (Staal, Nin Pratt and Jabbar 2008), but with recent economic growth and more rapid urbanization there is currently a window of opportunity for improving technology adoption in the dairy sector. The benefits are potentially very large. Milk yields of domestic Ethiopian breeds range from 15 to 25 percent of the yields obtained by foreign breeds and hybrids (Gebremariam et al. 2010). Moreover, Ethiopia's public agricultural sector has historically underinvested in the livestock sub-sector, which has received just a few percent of the total budget, despite contributing around 40 percent to agricultural GDP. The seemingly large nutritional impacts of cow ownership would appear to provide further justification for scaling up the public sector livestock budget.

While productivity enhancement is likely to be integral at early stages of economic transformation in any agricultural sector, transformation of the dairy sector over the longer run ultimately requires the introduction of technologies for reducing the perishability and health risks of milk products, especially as the potential marketable surplus increases. In that regard there may be important lessons to be learned from the so called "White revolutions" of India (Cunningham 2009), neighboring Kenya, and other dairy success stories (Staal, Nin Pratt and Jabbar 2008). In those countries, the rapid growth of large urban centers provided strong demand-side drivers of transformation in the dairy sector, but so too did the introduction of improved small-scale technologies, and a range of other innovations across the value chain, including the use of milk cooperatives in some contexts. ${ }^{17}$ With milk consumption in Ethiopia being as low as it is, yet also demonstrably important for child growth, there are clearly strong grounds for strengthening existing efforts to transform the production and marketing of this essential source of child nutrition.

${ }^{17}$ The process of commercialization of an agricultural sector can, however, have some ambiguous effects on food consumption and nutrition. For an interesting example of dairy cooperatives in India, see Alderman (1994). 


\section{REFERENCES}

Alderman, H. 1994. Why should it matter what commodity is the source of agricultural profits? Dairy development in India. In Agricultural Commercialization, Economic Development, and Nutrition: ed. J. Von Braun and E. Kennedy. Baltimore: The Johns Hopkins University Press.

Bhutta, Z. et al. 2013. Evidence-based interventions for improvement of maternal and child nutrition: what can be done and at what cost? The Lancet. 382 (9890): 452-77.

Cunningham, K. 2009. Operation Flood's Role in India's Dairy Development. IFPRI Discussion Paper 00924, Washington DC.

CSA (Central Statistics Agency). 2010. Agricultural Sample Survey 2009/10 (2002 E.C.) Volume VII Report on crop and livestock product utilization (Private peasant holdings, Meher Season). Addis Ababa: CSA.

de Beer, H. 2012. Dairy products and physical stature: a systematic review and meta-analysis of controlled trials. Economics and Human Biology 10: 299-309.

de Janvry, A., M. Fafchamps and E. Sadoulet. 1991. Peasant household behavior with missing markets: some paradoxes explained. Economic Journal 101 (409): 1400-1417.

FAO. 2013. AGROSTAT. Rome: Food and Agriculture Organization. http://faostat.fao.org/default.aspx

Gebremariam, S., S. Amare, D. Baker, and A. Solomon. 2010. Diagnostic study of live cattle and beef production and marketing: Constraints and opportunities for enhancing the system. Report for the Agricultural Transformation Agency (ATA), Addis Ababa.

Hoorweg, J., P. Leegwater and W. Veerman. 2000. Nutrition in agricultural development: intensive dairy farming by rural smallholders. Ecology of Food and Nutrition 39: 395-416.

Hoppe C, C. Mølgaard, and K.F. Michaelsen. 2006. Cow's milk and linear growth in industrialized and developing countries. Annual Review of Nutrition 26: 131-73.

Hoppe, C., C. Mølgaard, A. Juul, and K.F. Michaelsen. 2004. High intakes of skimmed milk, but not meat, increase serum IGF-I and IGFBP-3 in eight-year-old boys. European Journal of Clinical Nutrition 58: 1211-1216.

lannotti, L., E. Muehlhoff, and D. McMahon. 2013. Review of milk and dairy programmes affecting nutrition. Journal of Development Effectiveness 5: 82-115.

LaFave, D. and D. Thomas. 2012. Farms, families and markets: New evidence on agricultural labor markets. Mimeo, Department of Economics, Duke University.

Leroy, J.L. and E.A. Frongillo. 2007. Can interventions to promote animal production ameliorate undernutrition? Journal of Nutrition 137: 2311-2316.

Marquis, G., J. Habicht, C. Lanata, R. Black, and K. Rasmussen. 1997. Breast milk or animal product foods improve linear growth of Peruvian toddlers consuming marginal diets. American Journal of Clinical Nutrition 66: 1102-1109.

Masset E., L. Haddad L., A. Cornelius, and J. Isaza-Castro. 2011. A systematic review of agricultural interventions that aim to improve nutritional status of children. EPPI-Centre, Social Science Research Unit, Institute of Education, University of London, London.

McLean, E., L. Allen, C. Numann, J. Peerson, J. Siekmann, S. Murphy, N. Bwibo, and M. Demment. 2007. Low plasma vitamin B-12 in Kenyan school children is highly prevalent and improved by supplemental animal source foods. Journal of Nutrition 137: 676-682.

MoARD (Ministry of Agriculture and Rural Development). 2007. Livestock Master Plan Study Phase I Report Volume T - Sociological Aspects. Addis Ababa: MoARD.

Mølgaard C, A. Larnkjær, K. Arnberg and K. Michaelsen. 2011. Milk and growth in children: effects of whey and casein. Nestle Nutrition Workshop Series, Pediatrics 67: 67-78.

Murphy, S. and L. Allen. 2003. Nutritional importance of animal source foods. Journal of Nutrition 133: 3932s-3935s.

Neumann, C., D. Harris and L. Rogers. 2002. Contribution of animal source foods in improving diet quality and function in children in the developing world. Nutrition Research 22: 193-220. 
Nicholson, C.F., L. Mwangi, S.J. Staal, and P.K. Thornton. 2003. Dairy Cow Ownership and Child Nutritional Status in Kenya. American Agricultural Economics Association (New Name 2008: Agricultural and Applied Economics Association).

Pimkina, S., R. Rawlins, C.B. Barrett, S. Pedersen and B. Wydick, 2013. Got milk? The impact of Heifer International's livestock donation programs in Rwanda, mimeo, Department of Economics, University of San Francisco.

Randolph, T., E. Schelling, D. Grace, C. Nicholson, J. Leroy, D. Cole, M. Dentment, A. Omore, J. Zinsstag, and M. Ruel. 2007. Invited Review: Role of livestock in human nutrition and health for poverty reduction in developing countries. Journal of Animal Science 85: 2788-2800.

Sadler, K. and Catley, A. 2009. Milk Matters: The role and value of milk in the diets of Somali pastoralist children in Liben and Shinile, Ethiopia. Feinstein International Center, Tufts University and Save the Children, Addis Ababa

Singh, I., L. Squire, and J. Strauss. 1986. Agricultural household models: Extension, application and policy. Baltimore: Johns Hopkins University Press.

Staal, S., C. Delgado and C. Nicholson. 1997. Smallholder dairying under transactions costs in East Africa. World Development. 25 (5): 779-794.

Staal, S.J., A. Nin Pratt and M. Jabbar. 2008. Dairy Development for the Resource Poor - A Comparison of Dairy Policies and Development in South Asia and East Africa. Pro-Poor Livestock Policy Initiative (PPLPI).PPLPI Working Paper No. 44-1, International Livestock Reserach Institute (ILRI), Nairobi.

Strauss, J. 1986. Estimating the determinants of food consumption and caloric availability in rural Sierra Leone, in Agricultural household models: Extension, application and policy, eds I. Singh, L. Squire and J. Strauss. Baltimore Johns Hopkins University Press.

Strauss, J. and D. Thomas. 1995. Human Resources: Empirical Modeling of Household and Family Decisions, in Handbook of Development Economics, Volume 3A, eds. J. Behrman and T.N. Srinivasan. Amsterdam: North-Holland.

Vella, V., A. Tomkins, J. Nviku and T. Marshall. 1995. Determinants of Nutritional Status in South-west Uganda. Journal of Tropical Pediatrics 41: 89-98.

Wiesmann, D., L. Bassett, T. Benson and J. Hoddinott. 2009. Validation of the World Food Programme's Food Consumption Score and Alternative Indicators of Household Food Security. IFPRI Discussion Paper 00870, International Food Policy Research Institute (IFPRI), Washington DC. 


\section{Acknowledgements}

We are grateful to Jef Leroy for discussions regarding the nutritional aspects of milk and other colleagues in Ethiopia with whom we are collaborating on the evaluation of Ethiopia's Agricultural Growth Programme. We acknowledge the helpful comments received from John Maluccio, seminar participants at ILRI-Addis Ababa and participants at the "Farm production and nutrition" workshop held at the World Bank in June 2013. This work has partly been supported by the Department for International Development (UK) through its funding of the Transform Nutrition Consortium.

\section{About ESSP}

The Ethiopia Strategy Support Program is an initiative to strengthen evidence-based policymaking in Ethiopia in the areas of rural and agricultural development. Facilitated by the International Food Policy Research Institute (IFPRI), ESSP works closely with the government of Ethiopia, the Ethiopian Development Research Institute (EDRI), and other development partners to provide information relevant for the design and implementation of Ethiopia's agricultural and rural development strategies. For more information, see http://www.ifpri.org/book-757/ourwork/program/ethiopia-strategy-support-program or http://essp.ifpri.info/ or http://www.edri-eth.org/.

\section{About these working papers}

The ESSP Working Papers contain preliminary material and research results from IFPRI and/or its partners in Ethiopia. The papers are not subject to a formal peer review. They are circulated in order to stimulate discussion and critical comment. The opinions are those of the authors and do not necessarily reflect those of their home institutions or supporting organizations.

INTERNATIONAL FOOD POLICY RESEARCH INSTITUTE 2033 K Street, NW | Washington, DC 20006-1002 USA $\mathrm{T}:+1.202 .862 .5600$ | F: +1.202.457.4439

Skype: ifprihomeoffice | ifpri@cgiar.org | www.ifpri.org

IFPRI-ESSP ADDIS ABABA

P.O. Box 5689, Addis Ababa, Ethiopia

$\mathrm{T}:+251.11 .617 .2000$ | F: +251.11.646.2318

mahlet.mekuria@cgiar.org | http://essp.ifpri.info
ETHIOPIAN DEVELOPMENT RESEARCH INSTITUTE

P.O. Box 2479, Addis Ababa, Ethiopia

$\mathrm{T}:+251.11 .550 .6066 ;+251.11 .553 .8633 \mid \mathrm{F}:+251.11 .550 .5588$

info@edri-eth.org | www.edri-eth.org

The Ethiopia Strategy Support Program (ESSP) is financially supported by the United States Agency for International Development (USAID) and the Department for Internationa Development (DFID) of the government of the United Kingdom and is undertaken as part of the CGIAR Research Program on Policies, Institutions, and Markets (PIM) led by the International Food Policy Research Institute (IFPRI). This publication has been prepared as an output of ESSP and has not been independently peer reviewed. Any opinions expressed here belong to the author(s) and do not necessarily reflect those of IFPRI, the Ethiopian Development Research Institute, USAID, DFID, PIM, or CGIAR. 